Article

\title{
Gender Inequalities and the Effects of Feminine Artworks on Public Spaces: A Dialogue
}

\author{
Hooshmand Alizadeh ${ }^{1,2}, *$, Josef Kohlbacher ${ }^{1}$, Rozhen Kamal Mohammed-Amin ${ }^{3}$ and Tabin Latif Raouf ${ }^{3}$ \\ ${ }^{1}$ Institute for Urban and Regional Research, Austrian Academy of Sciences, Austria; \\ E-Mails: hooshmand.alizadeh@oeaw.ac.at (H.A.), josef.kohlbacher@oeaw.ac.at (J.K.) \\ 2 Kurdistan Studies Institute, University of Kurdistan, Iran \\ ${ }^{3}$ Digital Cultural Heritage Research Center, Sulaimani Polytechnic University, Iraq; \\ E-Mails: rozhen.mohammed@spu.edu.iq (R.K.M.-A.), tabin.latif.r@spu.edu.iq (T.L.R.) \\ * Corresponding author
}

Submitted: 15 April 2021 | Accepted: 22 July 2021 | Published: 30 November 2021

\begin{abstract}
Feminist street art aims to transform patriarchal spaces into places of gendered resistance by asserting a feminist presence in the city. Considering this, as well as women's social life, their struggle against lingering forces of patriarchy, and relating features of inequality (domestic violence), there was a feminist installation artwork by the young Kurdish artist Tara Abdulla that shook the city of Sulaimani in Iraqi Kurdistan on 26 October 2020. She had prepared a 4,800-meter-long washing line covered with the clothes of 99,678 Kurdish women who were survivors of sexual and gender-based violence. They installed it along the busiest street of the city (Salim Street). She used this piece of feminine to express her reaction to the Kurdish society regarding, the abuse that goes on silently, behind closed doors. She also aimed towards normalizing women's bodies. After the installation, she received many controversial reactions. As her artwork was a pioneering project in line with feminist issues in Kurdistan which preoccupied the city for quite a while, the aim of this article is to investigate the diverse effects of her work on the current dialogue regarding gender inequality in the Kurdish society. To do this, we used the research method of content analysis on big data (Facebook comments) to investigate the public reactions of a larger number of locals. The Feminine effectively exposed some of the deep-rooted cultural, religious, and social barriers in addressing gender inequalities and silent sexual violence issues in the modern Kurdish patriarchal society.
\end{abstract}

\section{Keywords}

Facebook reactions; feminist street art; gender inequalities dialogue; Kurdish women; public space; Sulaimani

\section{Issue}

This article is part of the issue "Art and Design for Social Inclusion in the Public Sphere" edited by Karin Hannes (KU Leuven, Belgium).

(C) 2021 by the authors; licensee Cogitatio (Lisbon, Portugal). This article is licensed under a Creative Commons Attribution 4.0 International License (CC BY).

\section{Introduction}

Feminist street art aims to transform patriarchal spaces into places of gendered resistance by asserting a feminist presence in the city, through different artworks in which femininity is explored and patriarchalism is subverted (Ryan, 2016). Considering this, as well as women's social life, their struggle against lingering forces of patriarchy, and relating features of inequality (Mojab, 2005), particularly domestic violence, there was a feminist instal- lation artwork by the young Kurdish artist Tara Abdulla that shook the city of Sulaimani, in Iraqi Kurdistan on 26 October 2020. With the help of the Civil Development Organization, she had prepared a 4,800-meter-long washing line covered with the clothes of 99,678 Kurdish women who were survivors of sexual and gender-based violence. They installed them along the busiest street of the city starting from Nali Park near the city center through Salim Street to the Courthouse by hanging them between electricity poles (see Figure 1 ). The installation 

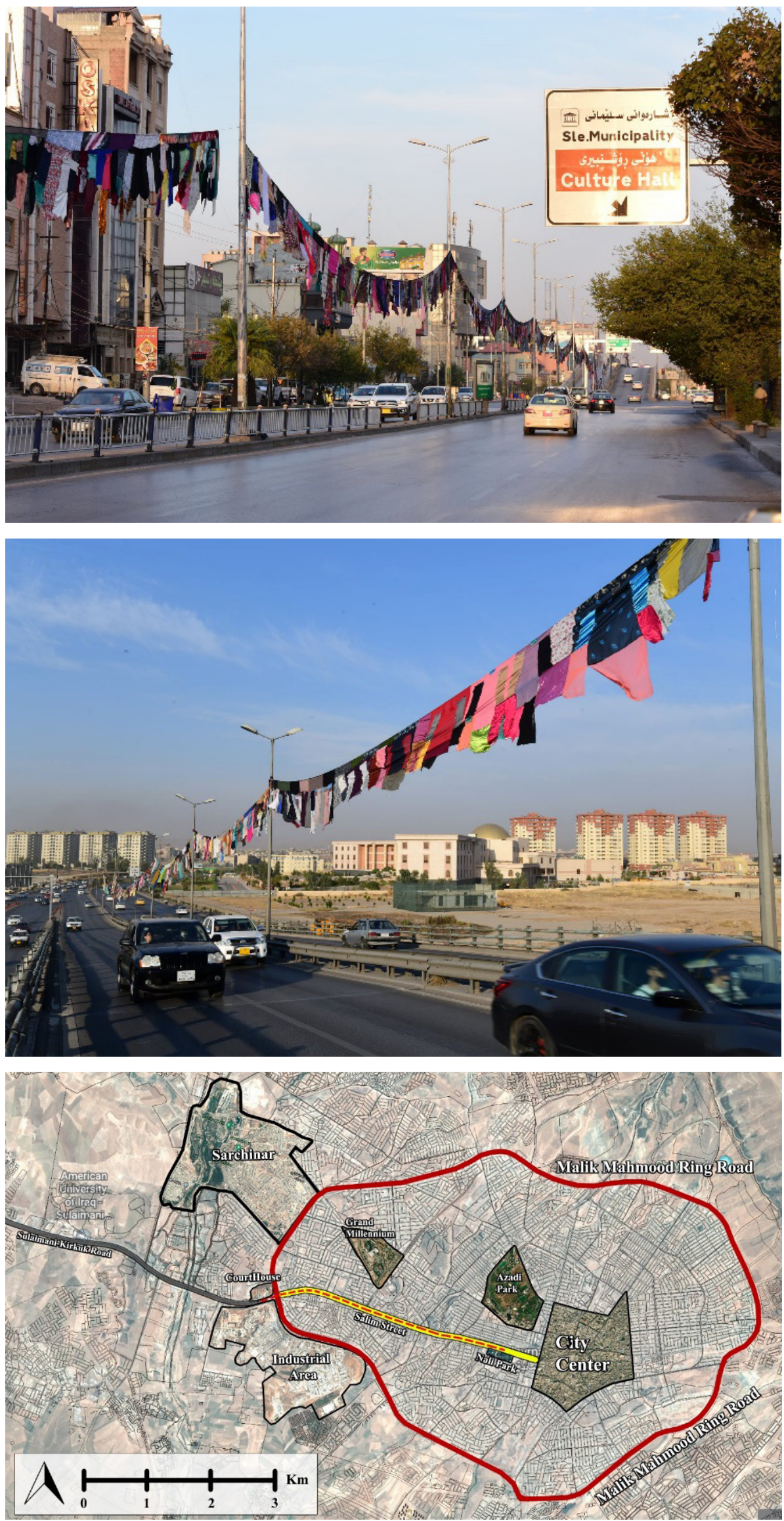

Figure 1. Feminist installation artwork and location along the course of Salim Street. Source: Photos taken from Abdulla (2020); map prepared by the authors. 
aimed at visualizing, exposing, and sparking public discussions around the pervasiveness of unspoken and silenced violence against local women. It also aimed at normalizing and disassociating women's bodies from shame by exposing the public to private and intimate pieces of clothing from local anonymous sexual violence survivors. She chose public space to bring the issue out of the private domain and show the people what was happening there.

After the installation, she received many controversial reactions and in a press conference she responded to the challenging questions. In an aftermath press conference, Tara attributed the urgent removal of her contemporary artwork to "the safety and security of the city" (Abdulrahman, 2020, p. 10), while announcing her plan to use the remaining pieces of the personal clothes in her next "shocking project" (BMC TV, 2020b). As her artwork was a pioneering project in line with feminist issues in Kurdistan, and since Sulaimani is a relatively progressive and cultural city with an outspoken public and the reputation of being a center for "revolutions" across the Kurdistan Regional Government (KRG) and the rest of Iraq, the removal of the artwork raised two key questions: How do socially conservative, religious, and patriarchal societies such as the Kurdish society react to publicizing and exposing sensitive topics involving sexual violence and deprivatizing women's bodies? How do public space and controversial artistic interventions contribute to widening and deepening debates on intolerance for sexual and gender-based violence? Therefore, the main aim of this article is to investigate the diverse effects of "the feminine" on the current dialogue regarding gender inequality in Kurdish society.

\section{State of the Research in Theoretical Discourse}

In the words of Foucault (1980, p. 149), "a whole history remains to be written about spaces-which would at the same time be the history of powers." This idea of (in)visible presence under the eye of power can be ascribed to the work of Henri Lefebvre, who argues that spatial patterns are not absolute, but are influenced by the social and economic systems of the institutions and individuals who exercise political power (Doan, 2010). This implies that the social systems effectively gendered spaces in favor of men and against women, even by carrying the names of men onto public spaces: streets, squares, and various institutions

The street's main "sociocultural function is to facilitate creative self-expression" (Riggle, 2016, p. 1) "that might not otherwise be experienced by [people] in the community" (Bacharach, 2018, p. 40). The opportunity to present a work in public space is to exhibit it visibly or to open up to experience something that has been undetectable or unseen before. This is in line with the words of Carmen Foncerrada in 1921, who differentiates the destiny of an artwork from a that of a museum: "Museums seem like cemeteries of illustrious men" (as cited in
Rojek, 2020, p. 77). Works of art should be in contact with the daily life of people. In the words of Bacharach, the street environment provides an important contextualizing base for the performance of art, which could not be achieved within the institutions, to communicate the issues of "those who are engaging in marginalization" (Bacharach, 2018, p. 40). Art has always been part of our collective commons, the means by which the fruits of imagination are ploughed back into shared experience. Unlike institutions, it can communicate more immediately, and "over a longer period of time, and more easily to a wider group of people-it's a way of getting one's voice out to those who need to hear it to change those institutional structures" (Bacharach, 2018, p. 40). This means that art also possesses an extraordinary power "to even fight against the stigma associated with sexual violence" (Di Lellio et al., 2019, p. 1546). This is clearer in the words of Louise Bourgeois and colleagues:

I'm afraid of power: It makes me nervous. In real life, I identify with the victim, that is why I went into art. In my art, I am the murderer....The process is to go from passive to active. As an artist I am a powerful person. (Bourgeois et al., 1998, p. 227)

Considering the social movements of feminism, which started their campaigns for visibility in public spaces applying both artistic practices and political strategies in the 1960s, the street became a discursive space in which identities, messages, socio-political concepts are presented and commented on. In this regard, feminist street art can act as a powerful platform for reaching the public and forming a public resistance against the patriarchal expectations and against the erasure of women in public space (Rojek, 2020). More importantly, such street art can be interpreted as an alternative way of doing politics or practicing resistance through the creative freedom of artists, in that "it provides a space and opportunity to contextualize and question dominant cultural codes and conventions" (Ryan, 2016, p. 8). In this regard, feminist street art aims to transform patriarchal spaces into places of gendered resistance by asserting a feminist presence in the city, in which femininity is explored and patriarchalism is subverted (O'Brien, 2016).

The process of normalization of women's issues is not an easy task, as "street artists often aim for risk, danger, and audacity gained from illegality in the materiality and meaning of artworks" (Chackal, 2016, p. 360) as best exemplified in a series of street artworks by Tatyana Fazlalizadeh in New York. She highlighted her artworks under the title Stop Telling Women to Smile by depicting non-smiling portraits of women above certain slogans, such as "Women: Not Here for Your Entertainment" or "My Name Is Not Baby": "These works provide an opportunity for the women who were silenced by the harassment to regain their voice" (Bacharach, 2018, p. 36). Similar to this, one can mention MissMe's Vandals works in Montréal, which, through the artistic placement of 
wheat-pasted characters, try to transform inherently patriarchal built space to generate dialogue around the issues that affect women, such as safety within urban centers, violence against women, racism, and colonization (Harris, 2019). In another example, we can add the feminist street artwork of the Mexican artist Mónica Barajas. She has used different artworks in the forms of mural paintings in the street environment to express the voices of powerless people for justice and equality. For her, the street environment is a democratic, open, and free of charge public sphere in which the walls can be transformed into a storybook "to be read as an article or a report we were never supposed to hear of" (Perez-Rodriguez et al., 2018, p. 90).

For the issue of women survivors of conflict-related sexual violence, we can highlight two recent projects in different urban contexts. The first one is the feminine artwork of Alketa Xhafa-Mripa in Kosovo, whose installation artwork in 2015 was titled Thinking of You and dealt with the hidden and private issues of women survivors of sexual violence in Kosovo's period of conflict during 1998-1999 (Di Lellio et al., 2019). She gathered thousands of skirts and dresses of those women to hang on washing lines across the main football stadium in Pristina. Based on her description, it was an installation art "to bring [women's] issues into the man's world, to a public place," to break the silence of survivors and "to end the culture of isolation and shame that enfolded survivors" (Hardi, 2020). For her, "that's what makes art work worthwhile: having access to masses, making a work under the skyline that is accessible to everyone, not only to a few" (Mripa, 2015). The second example refers to the artwork of Turkish artist Vahit Tuna, who covered the two towering blank façades of a building overlooking a busy Istanbul street, with 440 pairs of high heels. The main aim of this installation was "to symbolize the number of women murdered in domestic or sexual violence in Turkey in 2018" (Hudson, 2019). This installation was presented in the public realm because the artist wanted passersby to see the work as an alarming visual message that influenced their emotions and made them think about violence against women. In this case, shoes were chosen instead of clothing due to a Turkish tradition where shoes of someone who passed away are left outside of her/his house to prevent any further dying (Hardi, 2020). The ultimate aim of the creation of such emotional public awareness in both projects is to affect the public and change "the members of that public from sympathetic into committed spectators" to justice (Di Lellio et al., 2019, p. 1554).

\section{The Feminine Installation}

The Feminine was a short-lived public art project installed in a prominent public space in Sulaimani. Unlike much smaller and private Kurdish artworks, this large and public washing line-like installation deliberately placed the "private" clothing pieces of the survivors, such as bras and underwear, on top of the other less private and intimate pieces of the displayed clothes. This was meant to be and was perceived as a bold and controversial statement in a traditional and patriarchal society that too often associates women's bodies with sex, shame, and honor. The young Kurdish female artist had crowdsourced the clothing pieces from the survivors by knocking on the doors of thousands of welcoming and unwelcoming residents of Sulaimani, Halabja, and Chamchamal over three months of research and preparation (Abdulrahman, 2020).

Choosing a public space for spatializing a potentially dividing art installation was a key component in the design and execution of The Feminine. Unlike indoor galleries and exhibition spaces, public space helps with exposing her non-traditional art to "regular" people and the whole community and not only to a handful of appreciative elites or artists (Abdulla, 2020). Tara believed that Salim Street, with its massive users from different backgrounds, would help the "revolution" she wanted to start, disrupting the status quo and the normalization of silent sexual violence. Being critical of the role of local women's rights organizations and their contribution, Tara wanted to undertake an artistic and public exposure-based approach to her women's rights advocacy. During the project opening press conference, Tara recalled how some of the women victims were considering her a "superman" for being willing to expose an ignored pain (BMC TV, 2020a). Through an analogy, she described her shocking and "dream" installation as a small step towards addressing a severe societal pain related to women that could not have been realized without the support and sponsorship of the Civil Development Organization.

The artist correctly predicted the outcome of her socalled "shocking installation." In just one day, the installation made it into the headlines, talks, social media posts, and comments of many local (and some international) media outlets, organizations, writers, artists, advocates, academics, politicians, and the general public of Sulaimani and other cities across the KRG. Hours after its unveiling, this public installation experienced violence and vandalism by some unknown youths who set some parts of the washing-line-like installation on fire. Although the installation was planned for two days of public display, Tara eventually removed her work before its scheduled time. While Tara denies anyone's role in her decision to remove the remaining parts of the installation, rumors from locals and opposition shadow media suggest that the removal followed the request of an influential female politician from a ruling political party in the city. In any event, the decision was an attempt to contain the vandalism and reactions of mass disapproval from an outraged and skeptical public that has grown impatient with the many political and economic turmoil the region has been experiencing. 


\section{Women in Sulaimani City}

Sulaimani city is a relatively mountainous city in the northeast of Iraq and southeast of the Kurdistan Region of Iraq. Despite ongoing archaeological findings from thousands of years ago, the founding of Sulaimani as a city dates back to 1784 by Prince Ibrahim (locally called Ibrahim Pasha Baban) from the Baban Emirate. As the capital of Sulaimani province and the second largest Kurdish city in Iraqi Kurdistan, the Sulaimani population was estimated at 847,447 inhabitants in 2019. Locally, the city is known and prides itself for its cultural diversity, openness, vocal, divided, and opinionated public. It has been officially designated Iraqi Kurdistan's cultural capital in 2012 and a UNESCO creative city of literature in 2019. Labelled "the Difficult City" by Saddam Hussein regime's military and security officials, the city has been the stage of many demonstrations, prosecutions, and local history-changing events. Political oppositions in the Kurdistan Region of Iraq are primarily based in Sulaimani.

As a Kurdish city, it has a largely socially conservative public. Still, less socially conservative, and sometimes even locally provocative, businesses, activities, and events are more occurring and tolerated in comparison to other cities within the Kurdistan Region of Iraq and the rest of country. Historically, Kurdish women, specifically Sulaimani women, have enjoyed higher freedom in comparison to the neighboring cultures (Alizadeh, 2007, 2012; Hassan, 2013). The city celebrates some of its historically influential women, including women dying in political demonstrations, through their status in some key areas of the city (Joly \& Bakawan, 2016). Locally, Sulaimani women are known for their liberal (or less conservative) appearance, talks, and behaviors. Still, the city often finds itself divided between its socially and religiously conservative and secular or non-religious dwellers.

\section{Methodology}

To investigate the research questions and understand the public reactions towards The Feminine, we undertook a content analysis of the public reactions to the related news and posts of a total of 10 popular and less popular media outlets in the KRG on Facebook, totaling 1530 unrestricted public comments (text and images). We chose Facebook from among other social media platforms because of its vast popularity and wide use across KRG. Facebook is becoming a "virtual public space" for daily public exchanges, dialogues, debates, and reactions on various affairs among locals from different genders, age groups, education levels, and ethnicities in Iraq. Facebook's speed in spreading news and its ubiquitousness has made it a powerful medium for informing or misinforming Iraq's largely young public opinion, as well as exposing, influencing, or judging social, cultural, economic, and even political affairs. In the context of Iraq, Facebook has become a "court of public opin- ion" that is used or misused by individuals, political parties, and other groups. Ruling and opposition political parties in the KRG fund hundreds of shadow media to spread propaganda, fake news, attack each other, and influence public opinion. It is therefore no coincidence that Facebook users were restricted or blocked during past mass demonstrations or the ISIS invasion (Ali, 2018; Saliba, 2019).

We used the content analysis research method on big data to investigate the public reactions of a larger number of locals with a more diverse profile and location. Content analysis refers to "any technique for making inferences by objectively and systematically identifying specified characteristics of messages" (Holsti, 1969, p. 14). It analyses data "within a specific context in view of the meanings someone-a group or a cultureattributes to them" (Krippendorff, 1989, p. 403). Also, our past research experience shows that in the context of highly socialized, politicized, and indirect cultures, such as the KRG, people tend to be less direct and genuine in expressing their actual beliefs, thoughts, and feelings on such sensitive and controversial topics in face-to-face interviews. Additionally, we believe that an anonymized online or paper-based questionnaire or survey could not have reached or collected reactions from such a diverse and large number of locals the same way Facebook posts did in more natural and self-expressive ways. Despite the recognized challenges related to the use of big data from Facebook or other social media platforms, we believe the benefits of our selected method to this type of research investigation in Iraq's context outweigh its risks.

Our data collection process started with identifying the Facebook pages of a total of 10 media outlets with different levels of local popularity, numbers of followers, and focus areas. We reviewed and quantified the number and content of the related video and text news items dealing with the installation and removal of the artwork. We then extensively reviewed, categorized, and quantified a total of 1530 unrestricted public comments from Facebook. As part of the review, we identified the number, types, and motives of the public textual and image reactions to the news. While the self-reporting nature of social media profiles creates limitations for fully verifying the demographic data (gender and location) of commentators, we took some data quality assurance measures to mitigate this limitation. Before assigning the gender and location of the commentators, we checked each commentator's publicly available information and photos thoroughly, to correlate their profile name, selfreported or unreported gender and location, and the number of self-identifying photos.

\section{Reactions to The Feminine Artwork}

Of the 1530 Facebook comments we analyzed, an overwhelming majority of $91.6 \%$ of the comments were negative, severely criticizing The Feminine from unknown locations (44.6\%), Sulaimani (27.8\%), Erbil (10.2\%), and 
other cities inside and outside Iraq. Of those, about $72 \%$ were self-identified as male, $26 \%$ were self-identified as female, and the gender of the remaining $2 \%$ was unknown. Such groupthink in Facebook reactions does not often take place in the public reaction of Sulaimani inhabitants, famous for its divided public opinion in many political, religious, economic, and social matters. Among the negative reactions, we identified six main types of motives or sources of provocation:

1. Publicizing private pieces of women's clothing in a busy public space.

2. Localizing the "sensitive" and "shameful" topic of sexual violence and exposing its massive scale.

3. Public shaming or fear of being judged by residents of neighboring cities (internal politics) from the association of sexual violence with Sulaimani.

4. The artist's gender, and her appearance associations.

5. Installing unusual objects in an unexpected public space.

6. Limited local exposure to and interaction with controversial public art installations.

Overall, the negative comments fall into one or more of the following five categories: (1) personally attacking and insulting the artist and her character and idea, (2) interpreting the artist's work as an insult to Kurdish or Sulaimani women, (3) considering the artwork a disgraceful act for local culture, the city, or the Islamic religion, (4) blaming local women's rights organizations, local authorities, political parties, or media, and (5) complaining about the negative visual effect of the temporary art installation on the street and city scenery. The majority $(65.3 \%)$ of the content of the negative reactions was emotional, extremely offensive, and used sarcastic and coarse language in Facebook's virtual public space to personally attack and degrade the artist in her appearance, ideas, and even manners. Male commenters composed the vast majority of this group. Some of the commenters in this group extended their offences and personal attacks to the artist's family and project team. Others went as far as encouraging or praising vandalism against the installation.

Another group of opposers (9\%) considered the installation to be an insult and disgrace for Sulaimani women since the installation revealed their private pieces of clothing or "falsely suggested" that Sulaimani women were sexually violated. Some of these deniers questioned the authenticity of the clothes collection process by suggesting that the clothes belonged to people who had donated them supporting refugees and displaced people, or that the clothes belonged to non-local women. Although lingerie stores in the busy city center of Sulaimani tend to display women's underwear in their exhibition windows or on storefront outdoor tables, the display of anonymized and "private" pieces of clothing in the public space, especially as they were alluding to the sensitive topic of sexual violence, generated strong public reactions and outcry. Despite some Kurdish women's influential role in their communities throughout Kurdish history (Bruinessen, 2001; Galletti, 2001; Mojab, 2005) and ongoing progress in local women's participation in social, government, and political affairs (Begikhani et al., 2018), traditional and socially conservative expectations directed at women largely manifest in public reactions to initiatives that reach beyond the traditional boundaries. Additionally, in the local context, hanging women's underwear in busy public spaces has a significant negative connotation. Historically, Kurdish clans or villages hung the underwear of the women of a defeated clan or village on top of the captured houses or villages to humiliate and publicly shame their male enemies. The trace of this practice can still be heard in the threats and insults of some locals in modern times. One of the opposers of The Feminine explicitly compared the installation with that historic woman degrading practice.

While we believe that the socially and (to some extent) religiously largely conservative Kurdish culture played a major role in the groupthink phenomenon we observed in the public reaction, a small percentage explicitly identified the temporary art installation as a disgrace and offense to local culture $(0.3 \%)$, the city $(2.5 \%)$, and the religion of Islam (1.8\%). The content of many of the comments made it clear that the provocation had to do with the message as well as the delivery style of the message, when it publicized personal, "private" pieces of clothing and exposed the large scale of local silent abuses and sexual violence.

Although no women's rights groups or organizations were directly or indirectly involved in the project development, some of the critics (4.4\%) blamed local women's rights groups, advocates, and organizations for inspiring and encouraging such "shameless" projects that would allegedly encourage other young women to stray away from their local culture and values as Tara was said to have done. These comments were made despite Tara's explicit and vocal criticism of women's rights organizations for the slow and inefficient fulfilling of their roles and their outdated approach towards exposing local women's pains and advancing their rights. Accusing these groups and organizations of conducting liberal and untraditional individual or collective female initiatives is quite common in the content of the KRG. In 2008, when the KRG parliament amended the Iraqi Personal Status Law to restrict polygyny in the region, many conservative and religious organizations and locals considered this a secular move against Islamic law. Many of these persons and institutions blamed and pointed fingers at women's rights organizations for "opening the eyes" of women, encouraging them to divorce and rebel against their religion, culture, and family. In his comment on one of The Feminine news posts, an opposer posted an unrelated photo of the female members of the High Council of Women's Affairs in the KRG with an overlay text stating: "Of the 12 women members of this council, nine of 
them are divorced. Who is responsible for this?" While no women's rights organization was specifically involved in the project, many other textual and image comments blamed these organizations. One of the most repeated comments was an image of a controversial mullah with a statement from him on The Feminine: "Women run to the NGOs to help them solve their problems, and they made them take off their underwear to hang them on the poles of the city!" The same controversial mullah had previously publicly described local women as "dinosaurs" on his self-funded TV channel.

A total of $1.3 \%$ of the commentators accused the local authorities and political parties of failing to have prevented the action or of failing to prosecute the artist. Local public opinion and media supporting the opposing parties have always considered local authorities' interference with political, administrative, or economically motivated demonstrations as directed against the KRG or as ruling a restriction of freedom of expression. Yet in the case of The Feminine, enough commentators were calling out against the authorities' inaction to prevent or stop the artist and her "provocative" and "shameful" installation.

A small percentage $(0.2 \%)$ complained about the promotional role of local media for the wide coverage of this controversial artwork that "degraded" Sulaimani women and the city. Some opposers in this group accused local media of hypocrisy and double standards in giving over-exposure to non-religious and out-of-norm activities such as this, while overlooking or ignoring coverage of religious activities. One opposer went into specifics when he compared how local media extensively covered the Feminine, while they offered little to no media coverage to an activity in which a group of Muslim women in Sulaimani prayed in Bardarki Sarai (the most famous public square in Sulaimani). Through a text overlay on an image of the praying women, the same opposer tried to show an alternative picture relating to the actions of other Sulaimani women. The content of this image and many of the comments it triggered provided a window into the mind of some of The Feminine opposers and their strong denial of the scale of sexual violence in their province. Some of the comments questioned the installation of such a "disgraceful" artwork in Sulaimani because the pieces of clothing came from other cities and towns adjacent to Sulaimani as well. These opposers considered the decision to install the artwork in Sulaimani as an attempt to distort the image and reputation of this "cultural capital." Some opposers used the installation location as a point of attack against the city and its more liberal attitudes. A sarcastic commenter explicitly insulted and shamed the city and its female population stating that "The Feminine makes it seem as if no Sulaimani woman was left unmolested."

The artist repeatedly pointed to the fact that her project aims at opening the dialogue and raising awareness about the widespread presence of silent sexual violence in all its recognized and unrecognized forms- everywhere, including the KRG. Still, the localization of the artwork's materials appeared to have intensified the negative reactions towards installation, especially from the residents of Sulaimani.

About $4 \%$ of the commenters justified their dissatisfaction from an aesthetic point of view and the installation's unpleasant negative scenery in the "cultural city." A much smaller percentage (0.6\%) explicitly denounced having such art installation in a public space, while $2.1 \%$ used emojis or images to express their dissatisfaction with The Feminine. A total of $8.5 \%$ of the negative comments combined two or three of the above negative reaction types.

A disproportionately lower percentage of the commenters were neutral (4.9\%) or were supporters of the art installation (3.5\%). Half of the few supporters supported the artist or the artwork. Many of the supporters praised the artist's bravery and fearlessness in exposing unspoken or unacknowledged abuses against women in patriarchal societies. After all, in Kurdish culture sex, sexual violence, and exposure or reference to women's private body parts are taboo. Too often, especially in more conservative areas and families, innocent women or victims of sexual violence are "honor killed" and buried in unmarked graves (Bindel, 2021). Therefore, sparking dialogues around these topics on such a scale and with such visibility is a bold and daring act by anyone, let alone a local female artist. Some of the commentators in this group complained about the mass offenses the artist and her artwork have been exposed to, considering the negative reactions as another form of deeply rooted gender inequality and bias against women. Some of installation's supporters considered the burning of parts of the installation by unknown youths as an attempt to cover up their sexual violence against women or silence their victims or anyone who would try to expose them.

Only two of the 1530 comments supported the installation from the point of view of tolerance to diversity. Except for a few women's rights and gender equality advocates, debate around The Feminine in media channels and these specific Facebook posts lacked the voice and comments of many influential women's rights organizations and advocates in Sulaimani and across the region. While the short duration of the installation may have limited the engagement of these organizations and individuals in the public debate, it also questions their role in local sexual violence debates and their support for other women's initiatives outside their own organizations and networks. Most of the support for the project appeared to have been expressed in different ways.

A survey on Facebook and discussions with the artist revealed that individual academics, women's rights advocates, writers, and journalists from Sulaimani have expressed their strong support for Tara and her work through supportive posts on their social media accounts, phone calls, and messages. However, these quiet supporters stayed outside the larger-scale, heated debates and reactions in the news coverage of popular and less 
popular media outlets. Strong negative reactions of the loud opposers and potential fear of personal attacks in social media may have contributed to the silence of many of The Feminine supporters as it appeared from our discussions with local men and women displaying points of view that are less socially conservative.

While 1530 comments cannot represent the views and opinion of Sulaimani, it does display a pattern of public reaction and a tone of dialogue related to a sensitive topic involving women and sexual violence. Although The Feminine was ultimately removed before its scheduled end date with almost no objection from key women's rights organizations, it succeeded in engaging the public on a massive scale.

In this regard, feminist street art can act as a powerful platform for reaching the public and forming a public resistance against the patriarchal expectations and against the erasure of women in public space (Rojek, 2020). More importantly, such street art can be interpreted as an alternative way of doing politics or practicing resistance through the creative freedom of artists, in that "it provides a space and opportunity to contextualize and question dominant cultural codes and conventions" (Ryan, 2016, p. 8).

\section{Conclusion}

As we reflected on the reaction of people since the controversial art installation by Tara, it first reaffirms the points that have been discussed in the theoretical discourse concerning the role of feminist street art installations in public space as a form of public resistance against the patriarchal expectations and the erasure of women in public space. Then, it highlighted some major challenges concerning human rights in general and women's rights advocacy in particular in Kurdish society. The Feminine revealed the motives and reaction types of local loud opposition to those who reveal and remind of sexual violence, and to dialogue initiators addressing the deprivatization of female bodies in the public domain. It also highlighted the blindspots and dualism of the Sulaimani public that usually accepts and tolerates different forms of diversity in their city, which they proudly call a cultural and diverse city across the KRG and in Iraq. The public art installation effectively exposed some of the deep-rooted cultural, religious, and social barriers in addressing gender inequalities and silent sexual violence issues in the modern Kurdish patriarchal society. It demonstrated how the combination of art and public space can force public reactions and dialogues on the unspoken, controversial, and taboo topics of sexual violence and the deprivatization of women's bodies. In addition, the vandalism against the public artwork and its urgent removal proved the influence of such artistic interventions in generating wide and strong public debates and dialogues. Furthermore, because it brought into the public sphere the issue of Kurdish women survivors of sexual and gender-based violence and their pain by communicating their emotions, it expanded the public sphere of knowledge and sounded an alarm signal, calling on activist women for more ongoing campaigns. Finally, the above review shows that, despite good progress in political participation (Al-Tamimi, 2018), Kurdish women in the KRG still require more efforts to be made towards the creation of an independent and unified women's movement, aimed at changing cultural mindsets in order to achieve equal rights to those enjoyed by men.

\section{Acknowledgments}

This article is a part of a research project that has received funding from the European Union's Horizon 2020 Research and Innovation Programme under the Marie Sklodowska-Curie grant agreement No. 836194.

\section{Conflict of Interests}

The authors declare no conflict of interests.

\section{References}

Abdulla, T. (2020). Shocking installation: pp. A feminine artwork in the busiest street of the Kurdish city of Sulaimani. Civil Development Organization.

Abdulrahman, S. (2020, November 18). A woman's art project in Sulaymaniyah arouses controversy. Medya News. https://medyanews.net/a-womensart-project-in-sulaymaniyah-arouses-controversy

Ali, S. (2018, July 15). Kurdistan indefinitely blocks social media networks at Baghdad's request: Ministry. Kurdistan24. https://www.kurdistan24.net/ en/story/16599-Kurdistan-indefinitely-blockssocial-media-networks-at-Baghdad\%E2\%80\%99srequest:-Ministry

Alizadeh, H. (2007). Changes conceptions of women's public space in the Kurdish city. Cities, 24(6), 410-421.

Alizadeh, H. (2012). The concept of privacy and space in Kurdish cities. In T. Edensor \& M. Jayne (Eds.), Urban theory beyond the West: A world of cities (pp. 149-168). Routledge.

Al-Tamimi, H. (2018). Effects of Iraq's parliamentary gender quota on women's political mobilization and legitimacy post-2003. Contemporary Arab Affairs, 11(4), 41-62.

Bacharach, S. (2018). Finding your voice in the streets: Street art and epistemic injustice. The Monist, 101(1), 31-43.

Banerjee, T., \& Loukaitou-Sideris, A. (2011). Companion to urban design. Routledge.

Begikhani, N., Hamelink, W., \& Weiss, N. (2018). Theorising women and war in Kurdistan: A feminist and critical perspective. Kurdish Studies, 6(1), 5-30.

Bindel, J. (2021, March 8). 'As if she had never existed': The graveyards for murdered women. Aljazeera. https://www.aljazeera.com/features/2021/3/8/ 
as-if-she-had-never-existed-the-graveyards-formurdered-women

BMC TV. (2020a, October 26). The opening of The Feminine project by artist Tara Abdulla [Online broadcast]. Facebook. https://www.facebook.com/ 957463584360619/videos/287720322307803

BMC TV. (2020b, October 27). Reasons behind the removal of The Feminine tableau. https://bmctv.krd/ Detail.aspx?jimare $=22060 \& \mathrm{fbclid}=$ IwARO_XLi1nDdck GNfZ_L-BHdez52rLM5aiKrO2C-IHdo8aBREwNvd2_ f9EY8

Bourgeois, L., Bernadac, M.-L., \& Obrist, H. U. (1998). Louise Bourgeois: Destruction of the father, reconstruction of the father: Writings and interviews, 1923-1997. Violette.

Bruinessen, M. v. (2001). From Adela Khanum to Leyla Zana: Women as political leaders in Kurdish history. In S. Mojab (Ed.), Women of a non-state nation: The Kurds (pp. 95-112). Mazda Publishers.

Chackal, T. (2016). Of materiality and meaning: The illegality condition in Street art. The Journal of Aesthetics and Art Criticism, 74(4), 359-370.

Di Lellio, A., Rushiti, F., \& Tahiraj, K. (2019). “Thinking of you" in Kosovo: Art activism against the stigma of sexual violence. Violence Against Women, 25(13), 1543-1557.

Doan, P. L. (2010). The tyranny of gendered spacesReflections from beyond the gender dichotomy. Gender, Place \& Culture, 17(5), 635-654.

Foucault, M. (1980). Power/knowledge: Selected interviews and other writings, 1972-1977. Pantheon Books.

Galletti, M. (2001). Western images of women's role in Kurdish society. In S. Mojab (Ed.), Women of a non-state nation: The Kurds (pp. 209-226). Mazda Publishers.

Hardi, C. (2020). Feminine: The feminist installation that shook Sulaimani. AUIS.

Harris, C. (2019). "For rage": Rape survival, women's anger, and sisterhood in Chaucer's Legend of Philomela. The Chaucer Review, 54(3), 253-269.

Hassan, S. S. (2013). Women and literature: A feminist reading of Kurdish women's poetry [Doctoral thesis, University of Exeter]. ORE Exeter. https://ore. exeter.ac.uk/repository/bitstream/handle/10871/ 13903/HassanS.pdf?sequence $=1$

Holsti, O. R. (1969). Content analysis for the social sciences and humanities. Addison-Wesley.

Hudson, A. (2019). Artist displays 440 pairs of high heels for women murdered in Turkey in 2018.
Reuters. https://www.reuters.com/article/us-turkeywomensrights-shoes-idUSKBN1W923G

Joly, D., \& Bakawan, A. (2016). Women in KurdistanIraq: Issues, obstacles and enablers. The International Journal of Human Rights, 20(7), 956-977.

Krippendorff, K. (1989). Content analysis. In E. Barnouw, G. Gerbner, W. Schramm, T. L. Worth, \& L. Gross (Eds.), International encyclopedia of communication (Vol. 1, pp. 403-407). Oxford University Press.

Lemer, G. (1993). The creation of feminist consciousness: From the middle ages to eighteen-seventy (Vol. 2). Oxford University Press.

Mehta, V. (2009). Look closely and you will see, listen carefully and you will hear: Urban design and social interaction on streets. Journal of Urban Design, 14(1), 29-64.

Mojab, S. (2005). Kurdish women. In S. J. A. A. Nağmābādī (Ed.), Encyclopedia of women and Islamic cultures: Family, law and politics (Vol. 2, pp. 358-366). Brill.

Mripa, A. X. (2015). Thinking of you. Alketa Xhafa Mripa. https://www.alketaxhafamripa.com/thinking-ofyou

O’Brien, L. J. (2016). "Artful Vandals": Urban interventions, street art and spatial feminisms [Master thesis, Concordia University]. Spectrum Research Repository. https://spectrum.library.concordia.ca/981775

Perez-Rodriguez, J. L., Robador, M. D., Albardonedo, A., \& Duran, A. (2018). Gildings from Andalusia: Materials used in different types of artworks along centuries. Journal of Cultural Heritage, 31, 112-121.

Preston, V., \& Ustundag, E. (2005). Feminist geographies of the" city": Multiple voices, multiple meanings. In L. Nelson \& J. Seager (Eds.), A companion to feminist geography (pp. 211-227). Blackwell.

Reus, T. G., \& Usandizaga, A. (2008). Inside out: Women negotiating, subverting, appropriating public and private space (Vol. 4). Rodopi.

Riggle, N. (2016). Using the street for art: A reply to Baldini. The Journal of Aesthetics and Art Criticism, 74(2), 191-195.

Rojek, K. (2020). The feminist street art from the western part of Mexico. Quart, 58(4), 76-91.

Ryan, H. E. (2016). Political street art: Communication, culture and resistance in Latin America. Taylor \& Francis.

Saliba, E. (2019, October 26). Protests in Iraq find an outlet to the world: Snapchat. Euronews. https:// www.euronews.com/2019/10/26/protests-iraq-findoutlet-world-snapchat-n1072266

\section{About the Authors}

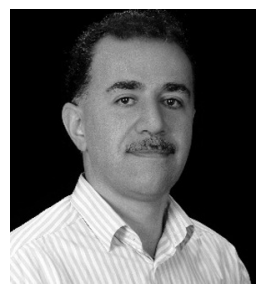

Hooshmand Alizadeh (PhD urban design) is senior postdoc researcher at the Austrian Academy of Sciences and associate professor at the Kurdistan Studies Institute, University of Kurdistan. He has more than fifteen years' teaching and research experience in urban studies, particularly dealing with different aspects of urbanism in general and public space in particular. His most important scholarly achievement is the development of the concept of Kurdish city in general and women's spatiality in specific. 


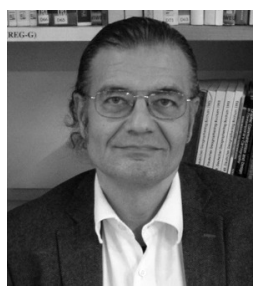

Josef Kohlbacher (PhD, DSocSci) is deputy director of the Institute for Urban and Regional Research of the Austrian Academy of Sciences in Vienna, Austria. For 30 years, his research focus has been on immigration and integration in the urban housing and labor markets, social coexistence in urban space, and migrant entrepreneurship. Since 2015, projects related to the Afghan diaspora communities in Austria have become another important component of his research.

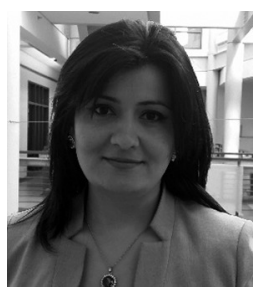

Rozhen Kamal Mohammed-Amin is an architect and academic. She is director of the Digital Cultural Heritage Research Centre at Sulaimani Polytechnic University where she also teaches, in the City Planning Department. She is co-director of the Nahrein Network and an honorary research fellow at University College London. She also serves as the secretary of RASHID International. Rozhen has professional and scholarly activities in 20 countries and is a recipient of numerous national and international appreciations, scholarships, awards, and fellowships.

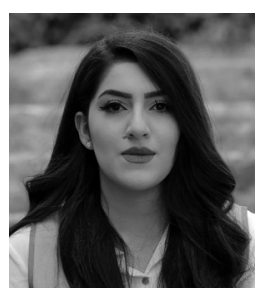

Tabin Latif Raouf is an urban planner. She works at the Sulaimani Polytechnic University as head of the design team and is a research assistant in the Digital Cultural Heritage (DCH) Research Center/ Nahrein Network, a UK government-funded collaborative network between University College London, University of Oxford, Sulaimani Polytechnic University, and the University of Al-Qadisiyah. She has contributed to the organization of many of DCH's national and international activities and events. She is also a teaching assistant at the Sulaimani Polytechnic University City Planning Department. 